\title{
Determination of stress-strain properties of thawing soils in oedometer
}

\author{
Mikhail Rabinovich*, Anastasia Alekseeva \\ Moscow State University of Civil Engineering, Yaroslavskoe shosse, 26, Moscow, 129337, Russia
}

\begin{abstract}
Article presents relation of thawing coefficient (Ath) and compressibility coefficient during thawing $(\mathrm{m})$ to the sampling depth and physical state of frozen soils in loams, typical for the Arctic region of the European part of Russia. Conclusions are drawn that help to predict thawing deformation of the tested soils according to their physical characteristics.
\end{abstract}

\section{Introduction}

Prediction of vertical deformation in permafrost soils during thawing usually consists of two classes of tasks [1] - prediction of temperature distribution in soil body and calculation of thawing settlement. Research on stress-strain properties of thawing soil is needed to calculate settlements and is rather difficult. The problem lies in the multicomponent nature of the frozen soil, thawing conditions, and dependence of the result on the physical properties of frozen soils and their ratios [2-5]. The value of the stress-strain properties is largely influenced by the cryogenic structure, moisture content and ice content.

Initially, tests to obtain stress-strain properties of thawing soils were carried out by V.P. Ushkalov [6], P.D. Bondarev [7], G.V. Porkhaev [8], G.I. Pakhomova [9], etc. It should be noted that the results were obtained under various test conditions, for example, tests were carried out up to the limiting value of thawing depth, and later, with defrosting, by $1 / 2$ of the plate diameter with a heating ring equal to $1 / 3$ of the die diameter, etc.

The work [10] compares the stress-strain properties data obtained in the field and in the laboratory conditions. The advantages of field measurement methods are noted, where the soil is investigated in natural conditions of occurrence. However, field tests of thawing soils are currently practically non-existent in engineering survey practice due to their high labor intensity and dependence on the time of year, harsh climate and tight deadlines, predetermine the choice of the test method.

\section{Methods}

Compression testing of frozen soil was carried out in accordance with the requirements of GOST 12248-2010 "Soils". Methods for laboratory testing of strength and deformability

*Corresponding author: RabinovichMV@mgsu.ru 
characteristics [11]. stress-strain characteristics were determined based on the results of compression tests (oedometer tests) of soil samples) (Fig. 1), which exclude the possibility of lateral expansion of the sample when it is loaded with a vertical load and is in a thawing state [12-14].

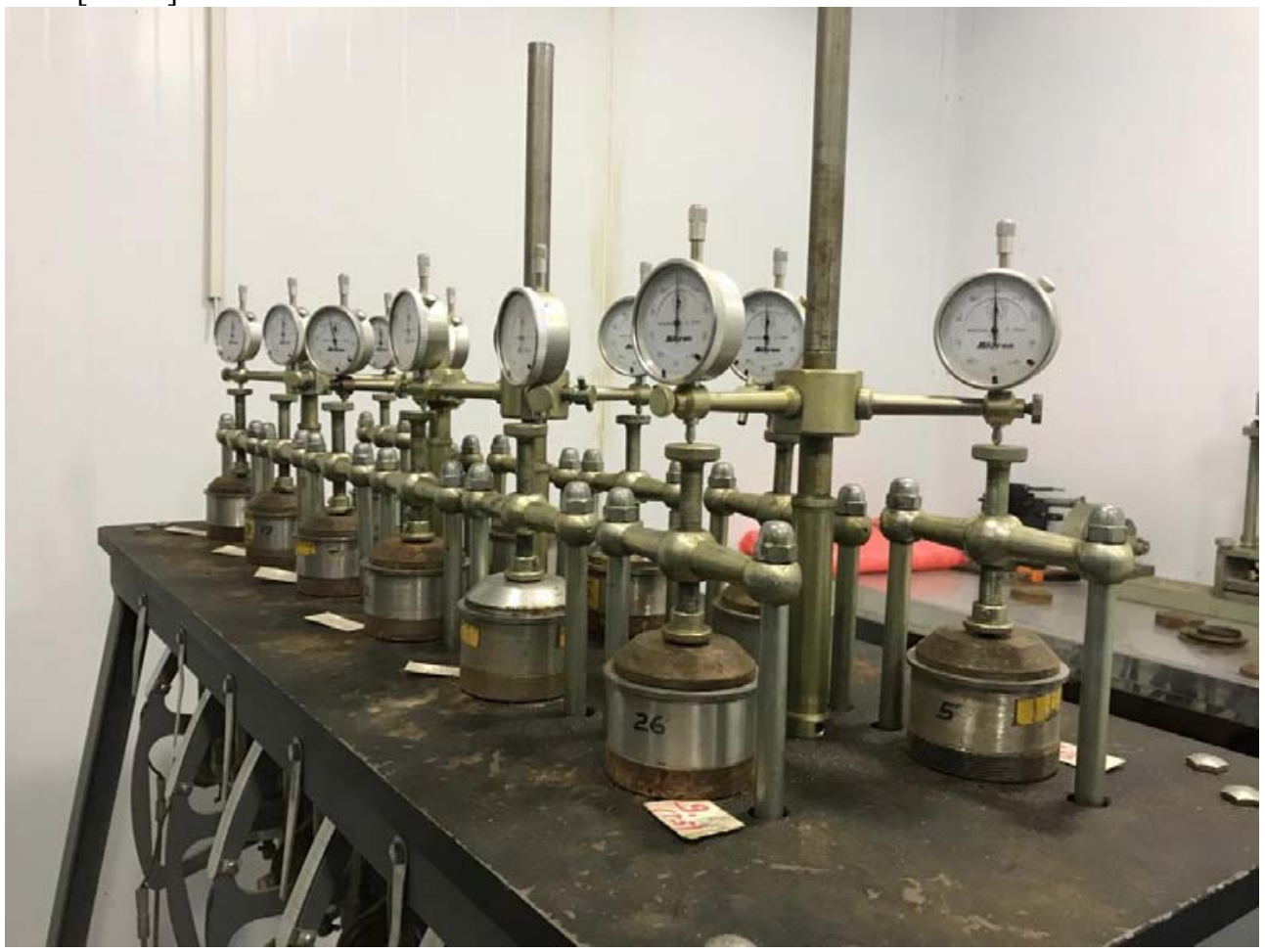

Fig. 1. Compression multi-chamber device for tests of thawing frozen soils in laboratory conditions. The device is placed in a special chamber under controlled temperature conditions in the range from positive to negative temperatures.

The aim of the study is to assess the deformation properties of thawing clayish soil and to identify patterns in the relation of the compressibility during thawing and physical characteristics of the soil. Samples of frozen loam, typical for the Arctic zone of the European part of the Russian Federation were taken in undisturbed structure with natural moisture and ice content with an index of pore filling with ice and unfrozen water close or equal to $100 \%$. The sampling depth for different samples was approximately 5, 10, 15 and 20 meters. The main averaged values of physical properties for the tested samples are shown in the table.

Table 1. Main averaged values of physical properties for the tested samples.

\begin{tabular}{|c|c|c|c|c|c|c|c|c|c|c|}
\hline \multirow{2}{*}{ 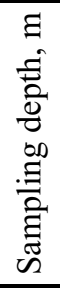 } & \multirow[b]{2}{*}{ 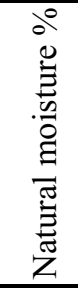 } & \multirow[b]{2}{*}{ 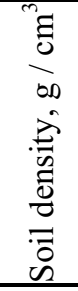 } & \multirow{2}{*}{ 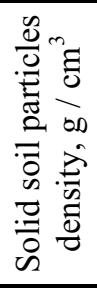 } & \multirow[b]{2}{*}{ 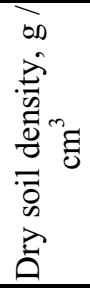 } & \multirow[b]{2}{*}{ 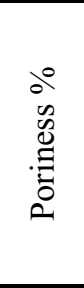 } & \multirow[b]{2}{*}{ 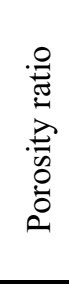 } & \multirow{2}{*}{ 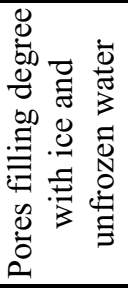 } & \multicolumn{3}{|c|}{ Plasticity } \\
\hline & & & & & & & & 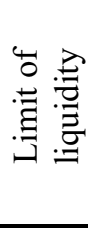 & 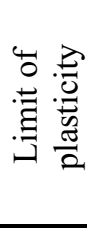 & 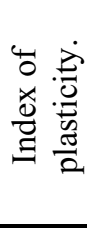 \\
\hline 5 & 41,2 & 1,72 & 2,69 & 1,22 & 54,7 & 1,21 & 0,99 & 29,9 & 16,7 & 13,2 \\
\hline 10 & 20,3 & 1,90 & 2,67 & 1,58 & 40,8 & 0,68 & 0,95 & 25,7 & 15,9 & 9,8 \\
\hline
\end{tabular}




\begin{tabular}{|l|l|l|l|l|l|l|l|l|l|l|}
15 & 19,0 & 2,05 & 2,68 & 1,72 & 35,7 & 0,56 & 0,98 & 24,8 & 14,0 & 10,8 \\
\hline 20 & 18,8 & 2,08 & 2,69 & 1,75 & 34,9 & 0,54 & 1,00 & 25,8 & 14,6 & 11,2 \\
\hline
\end{tabular}

The range of pressures for tests was set depending on the soil body stress state, with consideration of loads on the soil base and depth of the sample, temperature, moisture-ice content of the sample with the condition that minimum possible number of loading steps was taken according to the recommendations of GOST.

All tests were carried out in the range from 0.5 to $3.0 \mathrm{~kg} / \mathrm{cm}^{2}$, with a step of $0.5 \mathrm{~kg} /$ $\mathrm{cm}^{2}$. First loading step of the soil in the frozen state was applied until the stabilization of the vertical deformation and lasted from 1 to 3 days, after which frozen soil was allowed to thaw in a natural way before further loading in steps were applied. At each step, test lasted until stabilization. In total, the sample tests lasted from 5 to 10 days, in some cases reaching up to 14 days.

\section{Results}

Values of the thawing coefficient (Ath) and the compressibility coefficient during thawing (m) were determined according to the results of completed series of tests. Averaged test results are shown in the following graphs (Fig. 2,3,4,5), each of which corresponds to the samples taken from a depth of $5,10,15$ and $20 \mathrm{~m}$, respectively.

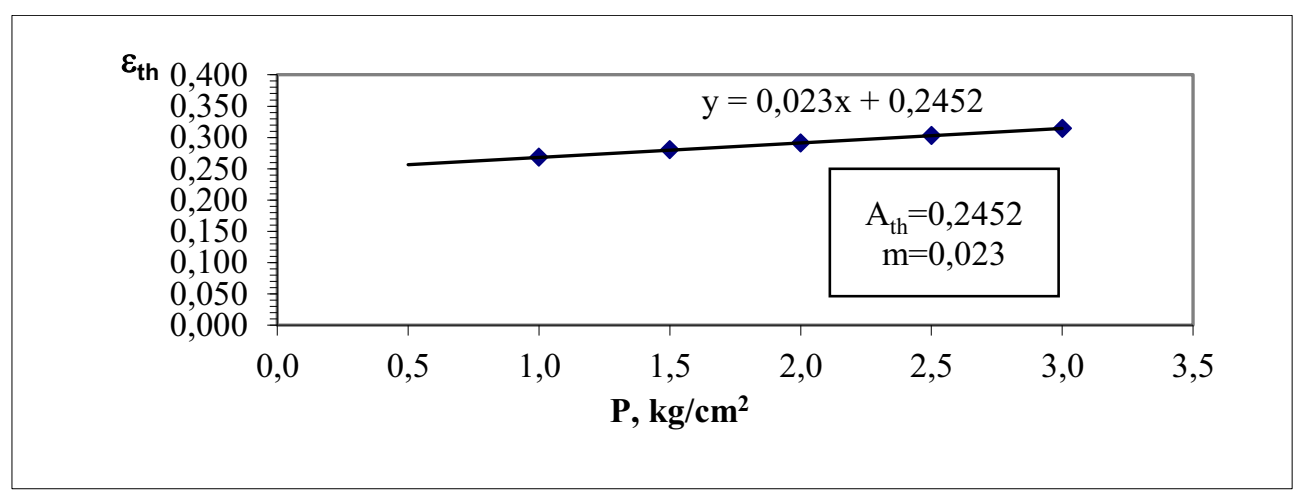

Fig. 2. Relations of thawing deformation to vertical pressure for sample from a depth of $5 \mathrm{~m}$.

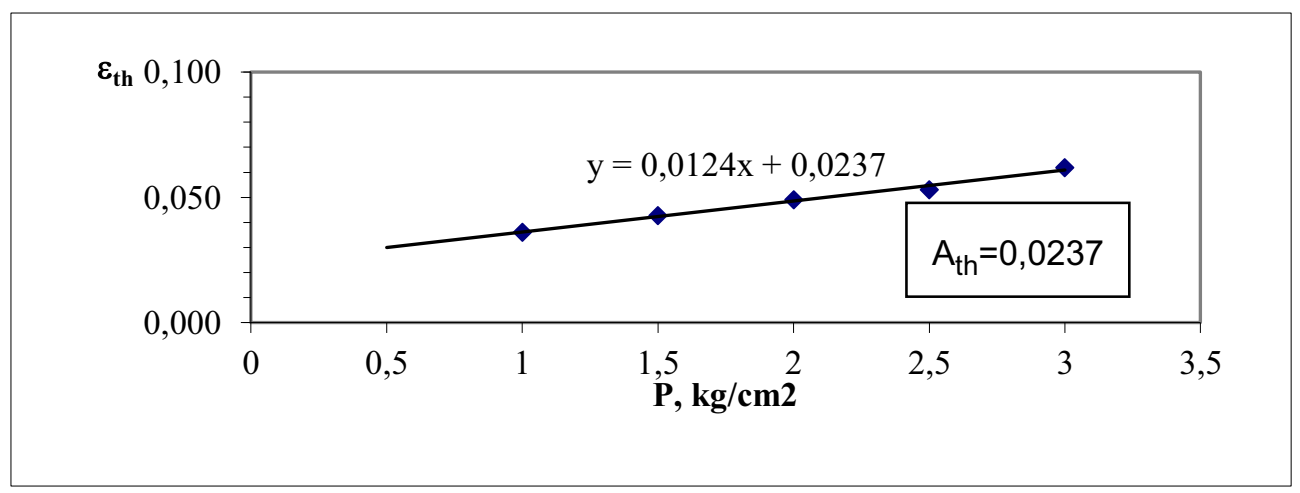

Fig. 3. Relations of thawing deformation to vertical pressure for sample from a depth of $10 \mathrm{~m}$. 


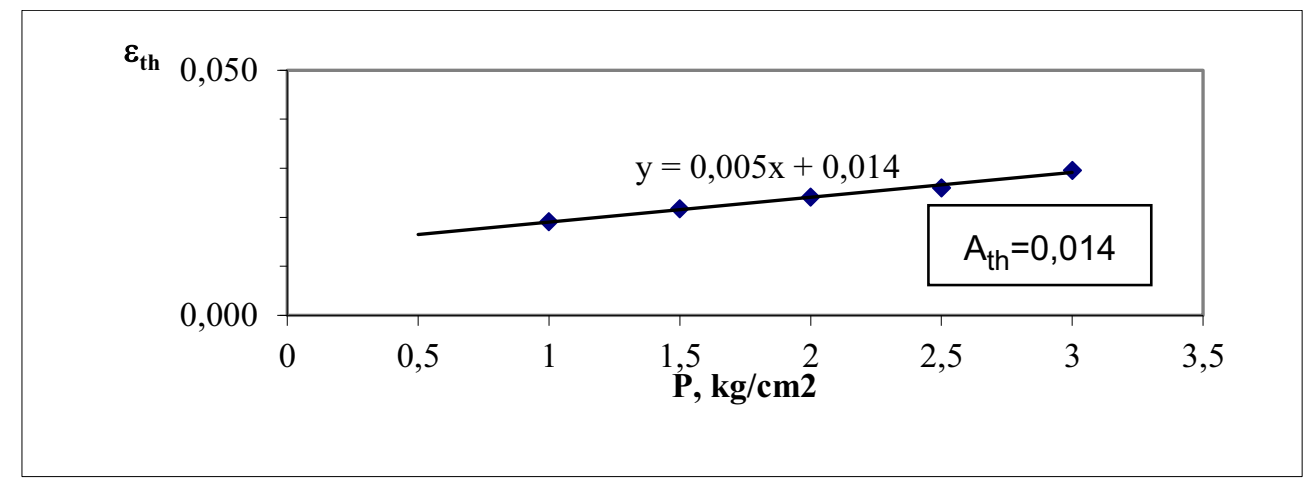

Fig. 4. Relations of thawing deformation to vertical pressure for sample from a depth of $15 \mathrm{~m}$.

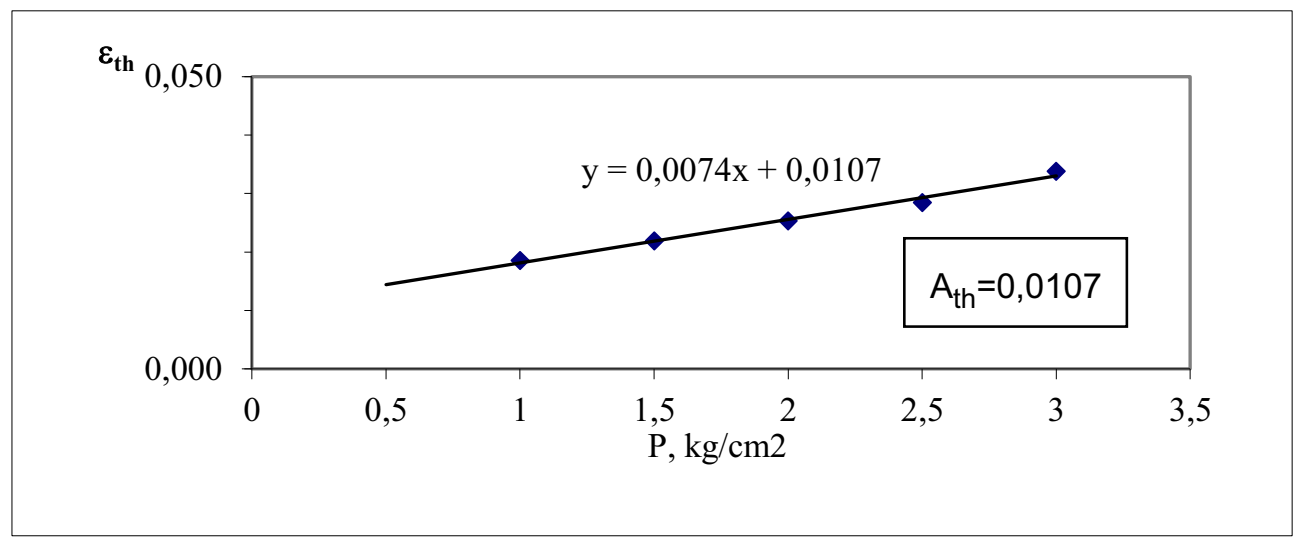

Fig. 5. Relations of thawing deformation to vertical pressure for sample from a depth of $20 \mathrm{~m}$.

\section{Discussion}

Previously published data on deformations of frozen soils during thawing [15-19] differ significantly and show a significant scatter of readings. Sometimes the values of the thawing coefficient (Ath) for seemingly similar soils can differ by an order of magnitude. The reason for that might be the fact that such results were obtained during tests of samples of different sizes and textures, from soils with incomparable values of moisture, ice content, density.

Aim of these studies, as noted above, was to study the properties of frozen loams typical for the Arctic zone of the European part of the Russian Federation.

Evidently, thawing settlement to a large extent, sometimes up to $70 \%$, depends on the ice content. In this case, with surface soils, ice content is twice as high than in soil strata from $15 \mathrm{~m}$ to $20 \mathrm{~m}$.

During comparison of the sample test results with decreasing porosity and humidity, the relation to the thawing coefficient value is clearly traced. Laboratory tests have fully confirmed this relation, while field tests by other researchers show significant variation.

\section{Conclusions}

Analysed test results revealed dependence of stress-strain values of thawing frozen soils on the depth of sampling and individual physical state properties of soils. The assessment 
criteria of deformability during thawing of frozen soils can be done with the following characteristics of the physical state of the soils: natural moisture, ice content, poriness (coefficient of poriness).

Comparison of results our tests with similar tests by other authors showed sufficient convergence, which makes it possible to make generalizations according to our results.

Preliminary calculations of subsidence capacity and choice on how to use permafrost soils as bases done by using physical state values of permafrost soils is justified from a technical perspective and evidently economically feasible.

\section{References}

1. SP 25.13330-2016 «Osnovaniya i fundamenty na vechnomerzlykh gruntakh»

2. 1977 Spravochnik po stroitel'stvu na vechnomerzlykh gruntakh. Pod red. Velli Yu.Ya. i dr. L. Stroyizdat 552

3. N.A.Tsytovich 1972 Mekhanika merzlykh gruntov. M. Stroyizdat

4. A.M.Pchelintsev 1964 Stroenie i fiziko-mekhanicheskie svoystva merzlykh gruntov Nauka 260

5. Klinova G.I. Aksenov V.I. 2010 Dzhakhangirova N.I. Opredelenie deformatsionnykh svoystv merzlykh gruntov pri ottaivanii. Zhurnal OFMG 3 21-25

6. Ushkalov V.P. 1962 Issledovanie raboty protaivayushchikh osnovaniy i ikh raschet po predel'nym deformatsiyam sooruzheniy. Iz-vo AN SSSR 220

7. Bondarev P.D. 1958 Osadka pri ottaivanii l'distykh gruntov poymy r. Oki v rayone Salekharda Tr. In-ta merzlotovedeniya, 19 Izd-vo AN SSSR 70-80

8. Porkhaev G.V., Tsvetkova S.G. 1958 K voprosu ob eksperimental'nykh metodakh opredeleniya osadki mnogoletnemerzlykh dispersnykh gruntov Tr. In-ta merzlotovedeniya, $19 \mathrm{Izd}$-vo AN SSSR 64-68

9. Pakhomova G.M. 1980 Osadki ottaivaniya gruntov v protsesse konsolidatsii. Avtoref. Dis ... kand. tekh. nauk:05.23.02 24

10. Kotov P.I., Roman L.T., Sakharov I.I., Paramonov V.N., Paramonov M.V. 2015 Vliyanie usloviy ottaivaniya $\mathrm{i}$ vida ispytaniy na deformatsionnye kharakteristiki ottaivayushchikh gruntov. Zhurnal OFMG 5 8-13

11. GOST 12248-2010 «Grunty. Metody laboratornogo opredeleniya kharakteristik prochnosti i deformativnosti»

12. Kal'bergenov R.G., Kotov P.I., Tsarapov M.N. 2019 Opredelenie deformatsionnykh kharakteristik ottaivayushchikh gruntov metodom trekhosnogo szhatiya. Zhurnal OFMG $128-32$

13. Gorelik Ya.B., Soldatov P.V. 2018 Metod rascheta vertikal'noy nagruzki na krep' skvazhiny pri ottaivanii vmeshchayushchikh merzlykh porod. Zhurnal Kriosfera Zemli 2

14. Pustovoyt G.P., Grechishcheva E.S., Golubin S.I., Avramov A.V. 2018 Vliyanie sposoba polucheniya iskhodnykh dannykh na prognoznye teplotekhnicheskie raschety pri proektirovanii v kriolitozone. Zhurnal Kriosfera Zemli 1

15. Sorokin V.A. 1981 O dostovernosti rezul'tatov laboratornykh kompressionnykh ispytaniy merzlykh gruntov na szhimaemost' pri ottaivanii. Ottaivayushchie grunty kak osnovaniya sooruzheniy 5-12

16. Rivkin F.M., Vlasova Yu.V., Parmuzin I.S. 2017 Zakonomernosti izmeneniya 
geokriologicheskikh usloviy v rezul'tate osadki merzlykh porod pri ottaivanii. Zhurnal Kriosfera Zemli $\mathbf{6}$

17. Grechishchev S.E. 2002 Osobennosti mekhaniki ustoychivosti ottaivayushchikh sklonov v rayonakh kriolitozony. Zhurnal Kriosfera Zemli 4

18. Cui Z., He P., Yang W. 2014 Mechanical properties of a silty clay subjected to freezingthawing Cold region science and technology 26-34

19. Grechishchev S.E., Chistotinov L.V., Shur Yu.L. 1984 Osnovy modelirovaniya kriogennykh fiziko-geologicheskikh protsessov Nauka 